\title{
Evaluation of the Physicochemical and Thermal Properties of Consciousness Energy Healing Treated Cefazolin Sodium
}

\author{
Alice Branton ${ }^{1}$, Mahendra Kumar Trivedii ${ }^{1}$, Dahryn Trivedi ${ }^{1}$, Gopal Nayak ${ }^{1}$ and Snehasis Jana ${ }^{2 *}$ \\ ${ }^{1}$ Trivedi Global, Inc., Henderson, USA \\ ${ }^{2}$ Trivedi Science Research Laboratory Pvt. Ltd., Bhopal, India
}

Submission: March 14, 2019; Published: April 12, 2019

*Corresponding author: Snehasis Jana, Trivedi Science Research Laboratory Pvt. Ltd., Bhopal, India

\begin{abstract}
Cefazolin sodium is a broad-spectrum first-generation cephalosporin antibiotic useful for the treatment of many bacterial infections. The aim of this research work was to estimate the impact of the Trivedi Effect ${ }^{\circledR}$ on the physicochemical and thermal properties of cefazolin using the modern analytical technique. Cefazolin sample was divided into control and treated parts. No Biofield Energy Treatment was provided to the control part of cefazolin; whereas, the treated part received Consciousness Energy Healing Treatment remotely by a distinguished Biofield Energy Healer, Alice Branton. The particle size values in the treated cefazolin were significantly increased by $11.44 \%\left(\mathrm{~d}_{10}\right), 3.15 \%\left(\mathrm{~d}_{50}\right), 2.35 \%\left(\mathrm{~d}_{90}\right)$, and $2.42 \%\{\mathrm{D}(4,3)\}$; hence, the specific surface area was decreased by $4.54 \%$ compared to the control sample. The evaporation and decomposition temperature of the treated cefazolin was increased by $27.56 \%$ and $0.12 \%$, respectively; however, the latent heat of evaporation and latent heat of decomposition was significantly altered by $1151.8 \%$ and $-53.75 \%$, respectively compared to the control cefazolin. The total weight loss was decreased by $6.57 \%$, but the residue amount was significantly increased by $137.5 \%$ in the treated sample compared with the control sample. The maximum thermal degradation temperature of the $1^{\text {st }}$ and $2^{\text {nd }}$ peak was significantly altered by $5.58 \%$ and $-28.66 \%$ in the treated sample compared with the control sample. The Consciousness Energy Healing Treatment might have introduced a new polymorphic form of cefazolin which may offer better powder flowability, smooth surface, and good thermal stability compared with the untreated sample. The treated cefazolin would be a more efficacious pharmaceutical formulation against cellulitis, urinary and respiratory tract infections, pneumonia, endocarditis, joint infection, genital infections, blood infections, etc.
\end{abstract}

Keywords: Cefazolin; The Trivedi Effect ${ }^{\circledR}$; Consciousness Energy Healing Treatment; Complementary and Alternative Medicine; Particle size; Surface area; DSC; TGA/DTG

\section{Introduction}

Cefazolin is a broad-spectrum first-generation cephalosporin antibiotic useful for the treatment of a number of both Gram-positive (i.e., Staphylococcus aureus, Staphylococcus epidermidis, Streptococcus pyogenes, Streptococcus pneumonia, Streptococcus agalactiae, and other strains of streptococci) and Gram-negative (i.e., Escherichia coli, Proteus mirabilis, etc.) bacterial infections $[1,2]$. Cefazolin act as a bactericidal (kills the bacteria) by inhibiting the bacterial cell wall biosynthesis by binding penicillin-binding proteins (bacterial proteins) and stops peptidoglycan synthesis, which is needed to maintain the cell wall [3]. It is used for the treatment of cellulitis, urinary tract infections (UTI), respiratory tract infections, pneumonia, endocarditis, joint infection, biliary tract infections, genital infections, blood infections (sepsis), and also prevent group B streptococcal disease in the time of delivery and before surgery, etc. [1-3]. General safety needs to follow while using cefazolin in pregnancy and breastfeeding as a small amount of cefazolin enters the breast milk [2,4]. Very common side effects associated with the cefazolin are diarrhea, stomach pain or upset stomach, vomiting, rash, blood dyscrasias, allergic skin reaction, etc. $[2,3]$. Chemical structure of cefazolin contains an N-methylimidazole (NMTD) side-chain releases free NMTD in the body, which can cause hypoprothrombinemia [5]. Cefazolin sodium is the sodium salt of cefazolin available in various dosage form, i.e., injectable, eye drop, powder for injection, etc. [6]. It is white or near white crystalline powder, freely soluble in water, slightly soluble in ethanol and methanol, and practically insoluble in acetone, chloroform, dichloromethane, ethyl acetate, and isopropanol; it has no fixed melting point, but decompose at the temperature of $\sim 193^{\circ} \mathrm{C}$ [7].

Physicochemical properties of the pharmaceutical or nutraceutical compounds play a crucial role in its dissolution, absorption, and bioavailability profile in the body [8]. Therefore, many scientific communities throughout the globe carrying out research work for the improvement of better physicochemical properties of the pharmaceutical and nutraceutical compounds in the formulations. With this aspect, the Trivedi Effect ${ }^{\circledR}$-Biofield Energy Heal- 
ing Treatment has the significant impact on the physicochemical properties such as particle size, surface area, and thermal behavior of pharmaceutical/ nutraceutical compounds [9-12]. The Trivedi Effect $^{\circledR}$ is a natural and only scientifically proven phenomenon in which a person can harness this inherently intelligent energy from the Universe and transmit it anywhere on the planet through the possible mediation of neutrinos [13].

This unique energy field exists surrounding the body of every living organism called the "Biofield", which is infinite and para-dimensional electromagnetic field. The Biofield based Energy Healing Therapies have been reported with significantly beneficial outcomes against various disease conditions [14]. The National Institutes of Health/National Center for Complementary and Alternative Medicine (NIH/NCCAM) recommend and included the Energy therapy under Complementary and Alternative Medicine (CAM) category in addition to other therapies, medicines and practices such as yoga, Qi Gong, Tai Chi, natural products, deep breathing, chiropractic/osteopathic manipulation, meditation, special diets, massage, progressive relaxation, guided imagery, acupuncture, acupressure, relaxation techniques, hypnotherapy, healing touch, movement therapy, Ayurvedic medicine, traditional Chinese herbs and medicines, homeopathy, essential oils, aromatherapy, Reiki, cranial sacral therapy, etc. The CAM has been well accepted by most of the U.S. people $[15,16]$. The impact of the Trivedi Effect ${ }^{\circledR}$-Consciousness Energy Healing Treatment has been published in numerous peer-reviewed scientific journals with the significant outcome on the various object(s). These scientific articles reported that the Biofield Energy Treatment (the Trivedi Effect ${ }^{\circledR}$ ) has the amazing capability to transform the physicochemical, structural, and behavioral properties of metals and ceramics [17-19], organic compounds [20,21], pharmaceuticals $[22,23]$, nutraceuticals $[24,25]$, improve the overall productivity of crops [26,27], as well as modulate the efficacy of various living cells $[28,29]$. Therefore, the current study was designed to evaluate the impact of the Trivedi Effect ${ }^{\circledR}$-Consciousness Energy Healing Treatment on the physicochemical, thermal, and behavioural properties of cefazolin sodium using powder X-ray diffraction (PXRD), particle size analysis (PSA), differential scanning calorimetry (DSC), and thermogravimetric analysis (TGA)/ Differential thermogravimetric analysis (DTG).

\section{Materials and Methods}

\section{Chemicals and Reagents}

Cefazolin sodium $\left(\mathrm{C}_{14} \mathrm{H}_{14} \mathrm{~N}_{8} \mathrm{O}_{4} \mathrm{~S}_{3}\right)$ was purchased from Tokyo Chemical Industry Co, Ltd., Japan and the other chemicals used during the experiments were of analytical grade available in India.

\section{Consciousness Energy Healing Treatment Strategies}

Cefazolin sodium was the test sample for the experiment, which further divided into two parts. One part of cefazolin was treated with the Trivedi Effect ${ }^{\circledR}$-Energy of Consciousness Healing Treatment remotely under standard laboratory conditions for 3 minutes by a distinguished Biofield Energy Healer, Alice Branton,
USA, and known as the Biofield Energy Treated cefazolin. However, the second part of cefazolin was considered as a control sample (no Biofield Energy Treatment was provided). Further, the control sample was treated with a "sham" healer for the comparison purpose. The "sham" was completely unknown about the Biofield Energy Treatment. After the treatment, the treated and untreated samples were kept in sealed conditions and characterized using PXRD, PSA, DSC, and TGA techniques.

\section{Characterization}

The PXRD, PSA, DSC, and TGA analysis of the control and Biofield Energy Treated cefazolin was performed. The PXRD analysis of cefazolin powder sample was performed with the help of Rigaku MiniFlex-II Desktop X-ray diffractometer (Japan) [30,31]. The average size of crystallites was calculated from PXRD data using the Scherrer's formula (1)

$$
G=k \lambda / \beta \cos \theta
$$

Where $\mathrm{G}$ is the crystallite size in $\mathrm{nm}, \mathrm{k}$ is the equipment constant (0.94), $\lambda$ is the radiation wavelength $0.154056 \mathrm{~nm}$ for $\mathrm{K} \alpha 1$ emission), $\beta$ is the full-width at half maximum, and $\theta$ is the Bragg angle [32]. Similarly, the PSA was performed using Malvern Mastersizer 2000, from the UK with a detection range between $0.01 \mu \mathrm{m}$ to $3000 \mu \mathrm{m}$ using the wet method $[33,34]$. The DSC analysis of cefazolin was performed with the help of DSC Q200, TA Instruments. The TGA/DTG thermograms of cefazolin were obtained with the help of TGA Q50 TA instruments [33,34].

The $\%$ change in particle size, specific surface area (SSA), peak intensity, crystallite size, melting point, latent heat, weight loss and the maximum thermal degradation temperature $\left(\mathrm{T}_{\max }\right)$ of the Biofield Energy Treated sample was calculated compared with the control sample using the following equation 2 :

$$
\% \text { change }=[\text { Treated }- \text { Control }] / \text { Control } \times 100
$$

\section{Results and Discussion}

\section{Powder X-ray Diffraction (PXRD) Analysis}

The PXRD experimental results indicated that the control and the Biofield Energy Treated cefazolin samples did not show clear, sharp, and intense peaks in the respective diffractograms (Figure 1). Thus, it was concluded that both samples were amorphous in nature and the Biofield Energy Treatment might not affect the crystallinity and pattern of the cefazolin (Figure 1).

\section{Particle Size Analysis (PSA)}

The PSD analysis of both the control and the Biofield Energy Treated cefazolin were performed, and the data are presented in (Table 1). The particle size values of the control cefazolin at $d_{10}, d_{50}$, $\mathrm{d}_{90}$, and $\mathrm{D}(4,3)$ were $4.72 \mu \mathrm{m}, 36.88 \mu \mathrm{m}, 167.03 \mu \mathrm{m}$, and $64.82 \mu \mathrm{m}$, respectively. Similarly, the particle sizes of the Biofield Energy Treated cefazolin at $\mathrm{d}_{10}, \mathrm{~d}_{50}, \mathrm{~d}_{90}$, and $\mathrm{D}(4,3)$ were $5.26 \mu \mathrm{m}, 38.04 \mu \mathrm{m}$, $170.96 \mu \mathrm{m}$, and $66.39 \mu \mathrm{m}$, respectively. Therefore, the particle size values in the Biofield Energy Treated cefazolin were significantly 
increased at $\mathrm{d}_{10}, \mathrm{~d}_{50}, \mathrm{~d}_{90}$, and $\mathrm{D}(4,3)$ by $11.44 \%, 3.15 \%, 2.35 \%$, and $2.42 \%$ compared to the control sample. The specific surface area of the Biofield Energy Treated cefazolin $\left(0.505 \mathrm{~m}^{2} / \mathrm{g}\right)$ was decreased by $4.54 \%$ compared to the control sample $\left(0.529 \mathrm{~m}^{2} / \mathrm{g}\right)$. Hence, it can be assumed that due to the Trivedi Effect ${ }^{\circledR}$-Consciousness Energy Healing Treatment the particle sizes of cefazolin were increased, hence decreased surface area. The larger particle size improves the powder flowability, smooth surface, good stability, and rapid dissolving rate $[7,35,36]$. Thus, it is anticipated that the Trivedi Effect ${ }^{\circledR}$ Treated cefazolin might offer better powder flowability, smooth surface, and good stability compared with the untreated sample (Table 1).
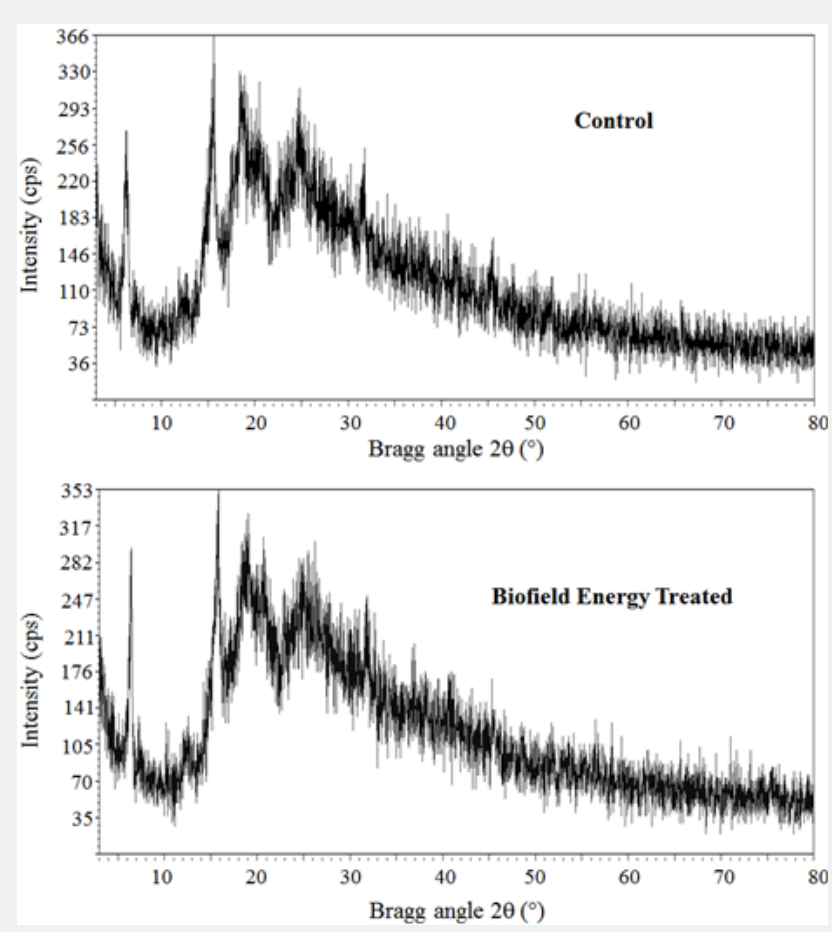

Figure 1: PXRD diffractograms of the control and the Biofield Energy Treated cefazolin.

Table 1: Particle size distribution of the control and the Biofield Energy Treated cefazolin.

\begin{tabular}{|c|c|c|c|c|c|}
\hline Parameter & $\mathbf{d}_{\mathbf{1 0}}(\boldsymbol{\mu m})$ & $\mathbf{d}_{\mathbf{5 0}}(\boldsymbol{\mu m})$ & $\mathbf{d}_{\mathbf{9 0}}(\boldsymbol{\mu m})$ & $\mathbf{D}(\mathbf{4 , 3})(\boldsymbol{\mu m})$ & $\mathbf{S S A}\left(\mathbf{m}^{\mathbf{2}} / \mathbf{g}\right)$ \\
\hline Control & 4.72 & 36.88 & 167.03 & 64.82 & 0.529 \\
\hline Biofield Treated & 5.26 & 38.04 & 170.96 & 66.39 & 0.505 \\
\hline Percent change* $\%)$ & 11.44 & 3.15 & 2.35 & 2.42 & -4.54 \\
\hline
\end{tabular}

$\mathrm{d}_{10}, \mathrm{~d}_{50}$, and $\mathrm{d}_{90}$ : particle diameter corresponding to $10 \%, 50 \%$, and $90 \%$ of the cumulative distribution, $\mathrm{D}(4,3)$ : the average mass-volume diameter, and SSA: the specific surface area. *denotes the percentage change in the Particle size distribution of the Biofield Energy Treated sample with respect to the control sample.

\section{Differential Scanning Calorimetry (DSC) Analysis}

The DSC analysis of both control and Biofield Energy Treated cefazolin were performed, and the thermograms are presented in Figure 2. The DSC thermograms of the control and Biofield Energy Treated cefazolin showed the sharp endothermic peak at $72.39^{\circ} \mathrm{C}$ and $92.34^{\circ} \mathrm{C}$, respectively (Figure 2). The thermogram pattern and melting point closely matched to the literature reported data [7]. The evaporation temperature of the Biofield Energy Treated cefazolin was significantly increased by $27.56 \%$ compared with the control sample (Table 2). Similarly, the control and Biofield Energy Treated samples showed exothermic peaks at $175.25^{\circ} \mathrm{C}$ and $175.46^{\circ} \mathrm{C}$, respectively (Figure 2). The decomposition temperature of the Biofield Energy Treated cefazolin was slightly increased by $0.12 \%$ compared with the control sample (Table 2). The melting and decomposition temperatures of the Biofield Energy Treated sample were improved compared to the control sample.
The latent heat of evaporation $\left(\Delta \mathrm{H}_{\text {evaporation }}\right)$ of the Biofield Energy Treated cefazolin $(156.1 \mathrm{~J} / \mathrm{g}$ ) was significantly increased by $1151.8 \%$ compared with the control sample $(12.47 \mathrm{~J} / \mathrm{g}$ ) (Table 2). Similarly, the latent heat of decomposition $\left(\Delta \mathrm{H}_{\text {decomposition }}\right)$ of the Biofield Energy Treated cefazolin (29.53J/g) was significantly decreased by $53.75 \%$ compared with the control sample (63.85J/g) (Table 2). As per the literature, any change in the latent heat of fusion can be attributed to the disrupted molecular chains and the crystal structure [37]. Thus, it can be predicted that the Trivedi Effect ${ }^{\circledR}$-Consciousness Energy Healing Treatment might be responsible for the disruption the molecular chains and crystal structure of cefazolin which was the cause of improved thermal stability of the treated sample compared with the control sample (Table 2),(Figure 2). 

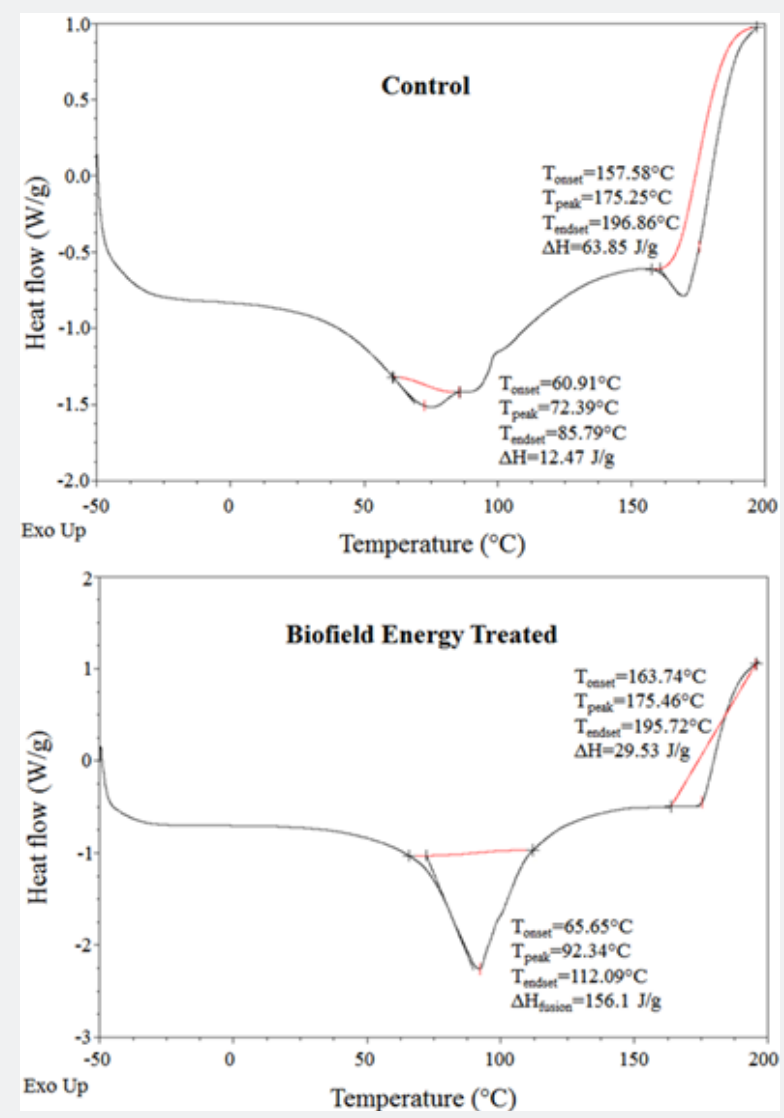

Figure 2: DSC thermograms of the control and the Biofield Energy Treated cefazolin.

Table 2: DSC data for both control and the Biofield Energy Treated samples of cefazolin.

\begin{tabular}{|c|c|c|c|c|}
\hline \multirow{2}{*}{ Sample } & \multirow{2}{*}{ Evaporation Temp $\left({ }^{\circ} \mathbf{C}\right)$} & Decomposition Temp $\left({ }^{\circ} \mathbf{C}\right)$ & Evaporation & \multicolumn{2}{|c|}{$\mathbf{\Delta H}(\mathrm{J})$} \\
\cline { 3 - 5 } & & & 12.47 & 63.85 \\
\hline Control Sample & 72.39 & 175.25 & 156.1 & 29.53 \\
\hline Biofield Energy Treated & 92.34 & 175.46 & 1151.8 & -53.75 \\
\hline \% Change* & 27.56 & 0.12 & Decomposition \\
\hline
\end{tabular}

$\Delta \mathrm{H}$ : Latent heat of evaporation/decomposition, ${ }^{*}$ denotes the percentage change of the Biofield Energy Treated cefazolin with respect to the control sample.

Thermal Gravimetric Analysis (TGA)/Differential Thermogravimetric Analysis (DTG)

The TGA thermograms of the control and Biofield Energy Treated cefazolin samples displayed three steps of thermal deg-

radation (Figure 3). The total weight loss in the Biofield Energy Treated cefazolin was significantly decreased by $6.57 \%$ compared with the control sample (Table 3). Therefore, the residue amount was significantly increased by $137.5 \%$ in the Biofield Energy Treated cefazolin compared to the control sample (Table 3).

Table 3: TGA/DTG data of the control and the Biofield Energy Treated samples of cefazolin.

\begin{tabular}{|c|c|c|c|c|}
\hline \multirow{2}{*}{ Sample } & \multicolumn{2}{|c|}{ TGA } & \multicolumn{2}{c|}{ DTG } \\
\cline { 2 - 5 } & Total weight loss (\%) & Residue \% & Peak 1 T $_{\max }\left({ }^{\circ} \mathbf{C}\right)$ & Peak 2 T \\
\hline Control & 95.44 & 4.56 & 185.18 & 819.04 \\
\hline Biofield Energy Treated & 89.17 & 10.83 & 195.51 & 584.33 \\
\hline \% Change* & -6.57 & 137.5 & 5.58 & -28.66 \\
\hline
\end{tabular}

${ }^{*}$ denotes the percentage change of the Biofield Energy Treated sample with respect to the control sample,

$\mathrm{T}_{\max }=$ the temperature at which maximum weight loss takes place in TG or peak temperature in DTG.

The DTG of the control and Biofield Energy Treated cefazolin the $1^{\text {st }}$ peak of Biofield Energy Treated sample was increased by exhibited two peaks in the thermograms (Figure 4). The $\mathrm{T}_{\max }$ of $\quad 5.58 \%$ compared to the control sample (Table 3). However, $\mathrm{T}_{\max }$ 
of the $2^{\text {nd }}$ peak of Biofield Energy Treated sample was significantly decreased by $28.66 \%$ compared to the control sample (Table 3). Overall, TGA/DTG of cefazolin samples revealed that the ther- mal stability of the Biofield Energy Treated sample was improved compared with the control sample.
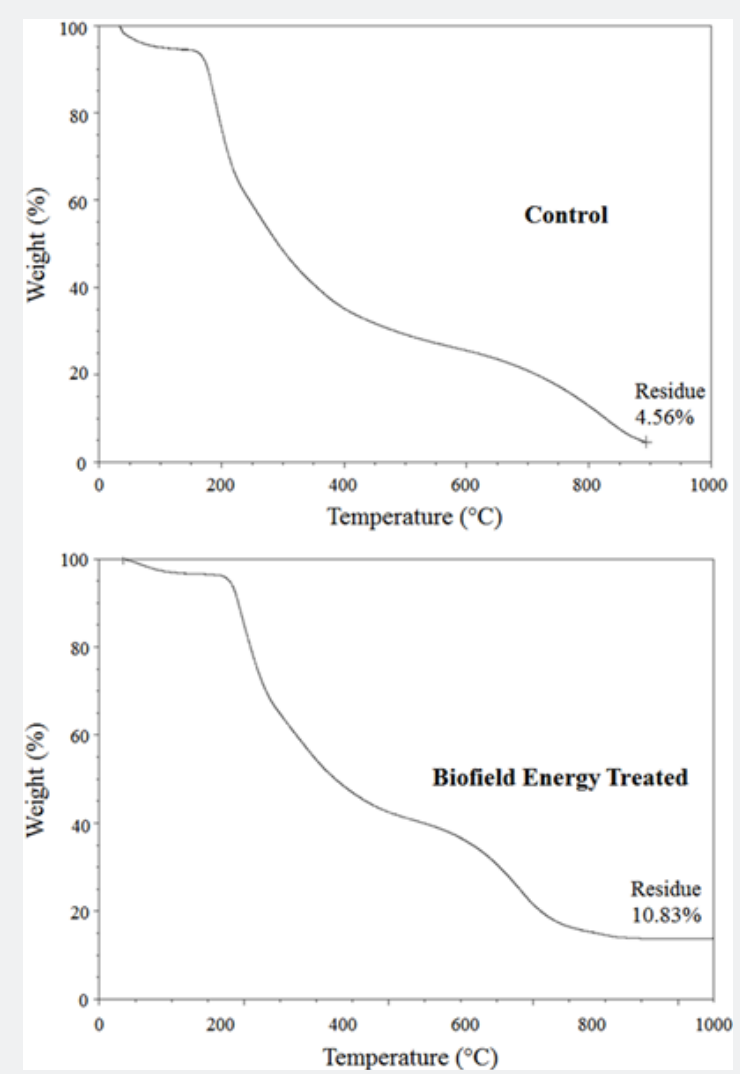

Figure 3: TGA thermograms of the control and the Biofield Energy Treated cefazolin.

\section{Conclusion}

The Trivedi Effect ${ }^{\circledR}$-Consciousness Energy Healing Treatment has a significant effect on the particle size, surface area, and thermal properties of cefazolin sodium. The particle size values in the Consciousness Energy Healing Treated cefazolin sodium were significantly increased by $11.44 \%, 3.15 \%, 2.35 \%$, and $2.42 \%$ at $\mathrm{d}_{10}$, $d_{50}, d_{90}$, and $D(4,3)$, respectively compared to the control sample. Hence, the specific surface area was decreased by $4.54 \%$ in the Biofield Energy Treated cefazolin compared to the control sample. The evaporation and decomposition temperature of the Biofield Energy Treated cefazolin was increased by $27.56 \%$ and $0.12 \%$, respectively compared with the control sample. However, the $\Delta \mathrm{H}$ evaporation was significantly increased by $1151.8 \%$, and $\Delta \mathrm{H}_{\text {decomposi- }}$ tion was significantly decreased by $53.75 \%$ in the Biofield Energy Treated sample compared with the control sample. Simultaneously, the total weight loss was significantly reduced by $6.57 \%$; hence the residue amount was significantly increased by $137.5 \%$ in the Biofield Energy Treated sample compared with the control sample. The $\mathrm{T}_{\max }$ was increased by $5.58 \%$ in the $1^{\text {st }}$ peak and significantly decreased by $28.66 \%$ in the $2^{\text {nd }}$ peak in the Biofield Energy Treated sample compared with the control sample. Overall, the thermal stability of the treated sample was improved compared with the control sample. Thus, the Consciousness Energy Healing
Treatment might have generated a new form of cefazolin which would offer better powder flowability, smooth surface, and excellent thermal stability compared with the untreated sample. The Consciousness Energy Healing Treated cefazolin would be very useful to design better pharmaceutical formulations that may offer better therapeutic response against cellulitis, UTI, respiratory tract infections, pneumonia, endocarditis, joint infection, biliary tract infections, genital infections, blood infections (sepsis), and also prevent group B streptococcal disease at the time of delivery and before surgery, etc.

\section{Acknowledgement}

The authors are grateful to Central Leather Research Institute, SIPRA Lab Ltd, Trivedi Science, Trivedi Global, Inc, Trivedi Testimonials, and Trivedi Master Wellness for their assistance and support during this work.

\section{References}

1. DailyMed - Cefazolin - cefazolin sodium injection, powder, for solution. (2018) dailymed.

2. Kusaba $T$ (2009) Safety and efficacy of cefazolin sodium in the management of bacterial infection and in surgical prophylaxis. Clinical Medicine Insights: Therapeutics. 1: 1607-1615.

3. Katzung, Trevor AJ (2015) Basic \& Clinical Pharmacology. New York: McGraw Hill Education: 776-778. 
4. Allegaert K, Van Mieghem T, Verbesselt R, Vanhole C, Devlieger R, et al (2009) Cefazolin plasma protein binding saturability during pregnancy. Methods Find Exp Clin Pharmacol 31(1): 25-28.

5. Stork CM (2006) Antibiotics, antifungals, and antivirals. New York: McGraw-Hill: 847.

6. How TH, Loo WY, Yow KL, Lim LY, Chan EW, et al. (1998) Chemical stability of pharmacy-compounded cefazolin sodium eye drops. J Clin Pharm Ther 23: 41-47.

7. Wang J, Qian Y, Zhang M, Wu J, Yang Z (2012) Cefazolin sodium pentahydrate crystal and its molecular assembly preparation method. United States Patent US 8,178,521 B2: 1-8.

8. Chereson R (2009) Bioavailability, bioequivalence, and drug selection In: Makoid CM, Vuchetich PJ, Banakar UV (Eds) Basic pharmacokinetics ( $1^{\text {st }}$ Edn) Pharmaceutical Press, London, UK.

9. Trivedi MK, Patil S, Shettigar H, Singh R, Jana S (2015) An impact of biofield treatment on spectroscopic characterization of pharmaceutical compounds. Mod Chem appl 3: 159.

10. Trivedi MK, Branton A, Trivedi D, Shettigar H, Bairwa K, et al. (2015) Fourier transform infrared and ultraviolet-visible spectroscopic characterization of biofield treated salicylic acid and sparfloxacin. Nat Prod Chem Res 3: 186

11. Trivedi MK, Tallapragada RM, Branton A, Trivedi D, Nayak G, et al. (2015) Physicochemical characterization of biofield energy treated calcium carbonate powder. American Journal of Health Research 3(6): 368-375.

12. Trivedi MK, Tallapragada RM, Branton A, Trivedi D, Nayak G, et al (2015) Evaluation of biofield energy treatment on physical and thermal characteristics of selenium powder. Journal of Food and Nutrition Sciences 3: 223-228.

13. Trivedi MK, Mohan TRR (2016) Biofield energy signals, energy transmission and neutrinos. American Journal of Modern Physics 5(6): 172176.

14. Rubik B, Muehsam D, Hammerschlag R, Jain S (2015) Biofield science and healing: history, terminology, and concepts. Glob Adv Health Med 4: 8-14.

15. Barnes PM, Bloom B, Nahin RL (2008) Complementary and alternative medicine use among adults and children: United States, 2007. Natl Health Stat Report 12: 1-23.

16. Koithan M (2009) Introducing complementary and alternative therapies. J Nurse Pract 5(1): 18-20.

17. Trivedi MK, Nayak G, Patil S, Tallapragada RM, Latiyal O (2015) Evaluation of biofield treatment on physical, atomic and structural characteristics of manganese (II, III) oxide. J Material Sci Eng 4: 177.

18. Trivedi MK, Tallapragada RM, Branton A, Trivedi D, Latiyal O, et al. (2015) Influence of biofield treatment on physical and structural characteristics of barium oxide and zinc sulfide. J Laser Opt Photonics 2: 122.

19. Trivedi MK, Nayak G, Patil S, Tallapragada RM, Latiyal O (2015) Studies of the atomic and crystalline characteristics of ceramic oxide nano powders after bio field treatment. Ind Eng Manage 4: 161.

20. Trivedi MK, Branton A, Trivedi D, Nayak G, Bairwa K, et al. (2015) Impact of biofield treatment on spectroscopic and physicochemical properties of p-nitroaniline. Insights in Analytical Electrochemistry 1: 1-8.

21. Trivedi MK, Branton A, Trivedi D, Nayak G, Bairwa K, et al. (2015) Physicochemical and spectroscopic characteristics of biofield treated p-chlorobenzophenone. American Journal of Physical Chemistry 4(6): 48-57.
22. Trivedi MK, Branton A, Trivedi D, Nayak G, Bairwa K, et al. (2015) Spectroscopic characterization of disulfiram and nicotinic acid after biofield treatment. J Anal Bioanal Tech 6(5): 265.

23. Trivedi MK, Patil S, Shettigar H, Bairwa K, Jana S (2015) Effect of Biofield Treatment on Spectral Properties of Paracetamol and Piroxicam. Chem Sci J 6: 98.

24. Mahendra KT, Rama MT, Alice B, Dahryn T, Gopal N, et al. (2015) Biofield Treatment: A potential strategy for modification of physical and thermal properties of gluten hydrolysate and ipomoea macroelements. J Nutr Food Sci 5(5): 414.

25. Mahendra KT, Gopal N, Shrikant P, Rama MT, Snehasis J, et al. (2015) Bio-field Treatment: An effective strategy to improve the quality of beef extract and meat infusion powder. J Nutr Food Sci 5: 389.

26. Trivedi MK, Branton A, Trivedi D, Nayak G, Mondal SC, et al. (2015) Evaluation of plant growth regulator, immunity and DNA fingerprinting of biofield energy treated mustard seeds (Brassica juncea). Agriculture, Forestry and Fisheries 4(6): 269-274.

27. Trivedi MK, Branton A, Trivedi D, Nayak G, Gangwar M, et al. (2015) Agronomic characteristics, growth analysis, and yield response of biofield treated mustard, cowpea, horse gram, and groundnuts. International Journal of Genetics and Genomics 3(6): 74-80.

28. Trivedi MK, Branton A, Trivedi D, Nayak G, Bairwa K, et al. (2015) Effect of biofield treatment on physical, thermal, and spectral properties of SFRE 199-1 mammalian cell culture medium. Advances in Biochemistry $3(6): 77-85$.

29. Trivedi MK, Branton A, Trivedi D, Nayak G, Bairwa K, et al. (2015) Physical, thermal, and spectroscopic characterization of biofield energy treated murashige and skoog plant cell culture media. Cell Biology 3(4): 50-57.

30. (1997) Desktop X-ray Diffractometer "MiniFlex+”. The Rigaku Journal 14: 29-36.

31. Zhang T, Paluch K, Scalabrino G, Frankish N, Healy AM, et al. (2015) Molecular structure studies of (1S,2S)-2-benzyl-2,3-dihydro-2-(1Hinden-2-yl)-1H-inden-1-ol. J Mol Struct 1083: 286-299.

32. Langford JI, Wilson AJC (1978) Scherrer after sixty years: A survey and some new results in the determination of crystallite size. J Appl Cryst 11: $102-113$.

33. Trivedi MK, Sethi KK, Panda P, Jana S (2017) A comprehensive physicochemical, thermal, and spectroscopic characterization of zinc (II) chloride using X-ray diffraction, particle size distribution, differential scanning calorimetry, thermogravimetric analysis/differential thermogravimetric analysis, ultraviolet-visible, and Fourier transform-infrared spectroscopy. International Journal of Pharmaceutical Investigation $7(1)$ : 33-40.

34. Trivedi MK, Sethi KK, Panda P, Jana S (2017) Physicochemical, thermal and spectroscopic characterization of sodium selenate using XRD, PSD, DSC, TGA/DTG, UV-vis, and FT-IR. Marmara Pharmaceutical Journal 21(2): 311-318.

35. Mosharrof M, Nystrom C (1995) The effect of particle size and shape on the surface specific dissolution rate of microsized practically insoluble drugs. Int J Pharm 122(1-2): 35-47.

36. Buckton G, Beezer AE (1992) The relationship between particle size and solubility. Int J Pharmaceutics 82(3): R7-R10.

37. Zhao Z, Xie M, Li Y, Chen A, Li G, et al. (2015) Formation of curcumin nanoparticles via solution-enhanced dispersion by supercritical $\mathrm{CO}_{2}$. Int J Nanomedicine 10: 3171-3181. 
(CC) Commons Attribution 4.0 License BY DOI: 10.19080/OMCIJ.2019.08.555738

\section{Your next submission with Juniper Publishers} will reach you the below assets

- Quality Editorial service

- Swift Peer Review

- Reprints availability

- E-prints Service

- Manuscript Podcast for convenient understanding

- Global attainment for your research

- Manuscript accessibility in different formats ( Pdf, E-pub, Full Text, Audio)

- Unceasing customer service

Track the below URL for one-step submission https://juniperpublishers.com/online-submission.php 